\title{
Czech Refugees in the Papers of the National Archives of Hungary Daniel MIKLÓS
}

\begin{abstract}
In the Czech Republic, the history of the Czech refugees who used the "Balkan Way" - that went through Hungary as well between 1939 and 1945 - is well known. However, due to the lack of knowledge of the Hungarian language, the Czech historians did not research the sources that can be found in the Hungarian archives. Although the Hungarian scholars could use those documents, they denied them, because - de iure - the Czech exiles weren't refugees according to the Hungarian government during World War II.

This essay tries to demonstrate that the National Archives of Hungary have important and nearly unknown documents about the Czech refugees. These people came through Hungary from the Protectorate of Bohemia-Moravia in order to join their Army in Exile in France or in the Middle East. The sources in the archives are documents of the Hungarian ministries, which can be essential for the Czech or Hungarian historians. By using them, we can examine the official treatment of the refugees in a broader perspective: for example, we can now answer questions like how the Hungarian government differentiated between the Poles and Czechs; or how could the Czechs reach Budapest after their illegal entry to Hungary.
\end{abstract}

\section{Keywords}

history, diplomacy, refugees, Czechoslovak-Hungarian relations, Czech-Hungarian relations, 1939-1940

\section{Introduction}

The following essay is based on the documents of the National Archives of Hungary, which can be helpful for the Czech researchers who are studying the history of the Czech refugees during the World War II. These sources were written in Hungarian, so the proper language knowledge is important to read these papers. It is a sad recognition that the Hungarian researchers have not used these materials to portray the history of the war refugees in Hungary on a bigger scale.

The history of Czech emigrants during World War Two is a not well known topic in Hungary, although numerous books, articles, essays and documentary movies were made about the exiles, refugees or prisoners of war. Who lived in Hungary between the years of 1939 
and 1945. Most of them were Poles, but they came also from France, Serbia, England, the Netherlands and even from Italy after 1943. These books analyze or depict the Hungarian supply system, which was organized by the Ministry of Interior (Belügyminisztérium) for the civilian refugees, and by the Ministry of Defense (Honvédelmi Minisztérium) for the military personnel. The Czechs were also treated by the Ministry of Interior, but they weren't recognized as political refugees, but as illegal border crossers. The Czech refugees in their memoirs often recalled this distinction: they came from an occupied country, and they wanted to fight in their Army, which was organized by their Government in Exile - like the Polish refugees did.

The different handling of the Poles came from the past. The Hungarian Prime Minister Pál Teleki in the autumn of 1939 referred to the old Polish-Hungarian friendship. Teleki denied the German claims, when they wanted to use the Hungarian railroad system to transport their military supplies during the Polish Campaign of 1939. It's worth to mention that Germany also disapproved the warm reception of the Polish refugees in Hungary, who came through the short lived common Polish-Hungarian border - which was established during the fateful days in March of 1939 for Czecho-Slovakia.

Czechoslovakia was the "Nemesis" of Hungary after the Peace Treaty of Trianon. As the common Hungarian sense said: Tomáš Garrigue Masaryk and Edvard Beneš were the destroyers of the Austro-Hungarian Monarchy, and they were also responsible for the territorial losses of Hungary. Beneš overshadowed Masaryk in the eyes of the Hungarian politicians who sometimes wanted to reattach the whole of the Slovakian territory and sometimes the part where the Hungarian minority lived. The pro-revisionist media campaign of Lord Rothermere, ${ }^{2}$ the mending Italian-Hungarian relation and later the improving German-Hungarian relations negatively influenced the connection between Budapest and Prague. Also the appeasement politics of Great Britain could help Germany to press its political and territorial claims. Czechoslovakia with the 3.5 million large German minority and with the developed industry was one of the main target of these claims. To disintegrate the state, Berlin also supported the Hungarian revisionism towards Czechoslovakia. The Little Entente couldn't oppose the resurgence of German power: the French support weakened, while the other member states (Romania, Yugoslavia) wanted to establish better relations with Germany and Italy.

In 1938 Czechoslovakia remained alone and the Munich Agreement, the final step of the appeasement politics, gave free hand to Germany to enforce the demands against Prague. After the Treaty of Munich the first Czechoslovak Republic collapsed, and President Beneš resigned, in Hungary it was seen like reparation for the interwar years. The public opinion in Hungary towards the Czechs after the departure of Beneš remained negative and the official relation also changed slowly between Czechoslovakia and Hungary: the failure of the negotiations in Komárom (Komárno) with the autonomous Slovak government, the border incidents, the problem with Kárpátalja (Podkarpatská Rus) and the unsolved economical

1 Pál Teleki (1879-1941): Hungarian politician who served as Prime Minister for two terms (1920-1921 and 19391941). In April of 1941 he committed suicide to protest against the Hungarian invasion of Yugoslavia.

2 Lord Rothermere, Harold Harmsworth (1868-1940): British media mogul and politician. In 1927 he wrote an editorial in his newspaper, the Daily Mail, under the title: "Hungary's Place in the Sun," in which he depicted his pro-Hungarian views. 
questions after the ethnical revision caused further problems in the Czechoslovak-Hungarian connection.

The cold relations between the two states explain why the Czechs tried to escape towards Hungary after the fall of Poland. Here they were also not warmly welcomed, but at least they could organize their units or travel to England or France by ships. Although, in the September of 1939, the situation changed for the Czechs. The northern safe route was shut down due to the occupation of Poland. If the Czechs wanted to escape from the Protectorate of Bohemia-Moravia, their way led through the Balkan.

The first illegal entry and state could be considered easy, because in Slovakia the exiles could count on secret organizations, or could get individual help from civilians. The next state was Hungary, where the Czechs met mostly with unfriendly behavior, and specific provisions in the law. In Yugoslavia the government supported the fleeing Czechs, nearly as enthusiastically as Hungary did the Poles. On the unofficial level, the Yugoslav government permitted the operation of the Czech cultural organizations which secretly handled the further transport of the emigrants. The situation changed in 1940, because Germany put Yugoslavia under pressure, and the Government due to this ceased the support of these organizations. ${ }^{3}$ It's also worth to mention that the Hungarian leadership was also under persistent German pressure regarding the refugees, mainly about the Poles. At last, in 1940 the Hungarian government disposed the Czechs towards Yugoslavia, which temporally ceased the German protests against the other refugees in the country.

When Yugoslavia fell in 1941, the last remaining, somewhat safe escape route, was closed for the Czechs. The escape from the Protectorate became risky, and the number of attempts decreased. In later periods during the war mainly individuals tried to leave the Protectorate, and join to the Czechoslovakian Army in Exile. It is interesting that later the Balkan route was "reopened" from the other end: during the Slovak National Uprising of 1944 partisans from the Titoist Army crossed Hungary to help the Slovakian irregulars. ${ }^{4}$

\section{Historiography}

It was already mentioned, that the history of the Polish refugees and prisoners of war is well documented. These works mainly centered the refugees, for example, István Lagzi made a massive and extensive work. Károly Kapronczay also published many books about the Poles; one under the title of Lengyel menekültek Magyarországon (Polish Refugees in Hungary, 1939-1945), ${ }^{5}$ he not only wrote about the Poles, but about other prisoners of the Second World War, who found shelter in Hungary. Until today this is the most extensive work about the refugees on Hungarian language. Due to the work of Lagzi, Kapronczay and other authors, the history of the Polish refugees is well researched: even their field post service is known, ${ }^{6}$ and also many Polish memoirs were translated to Hungarian.

3 BROD, Toman: Cesty československých uprchlíků přes Balkán v letech 1939-40, in: Československo a Juhoslávia, REPÁŇOVÁ, Vilma (ed.), Bratislava, 1968, 403.

4 HROZIENČík, Jozef: K otázke slovensko-juhoslavskej solidarity v boji proti fašizmu, in: Československo a Juhoslávia, REPÁŇOVÁ, Vilma (ed.), Bratislava, 1968, 385-393.

5 KAPRONCZAY, Károly: Lengyel menekültek Magyarországon, 1939-1945, Budapest 2009.

6 GAZDA, István Sr.: Magyarországi lengyel katonai táborok postája 1939-1944, Piliscsaba 2000. 
The second most "published" in the category were the French prisoners. In 1980, the

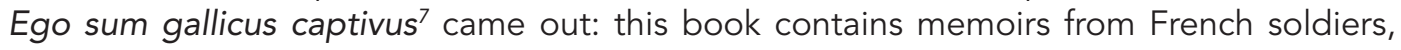
who fled from Germany to Hungary, after they heard about the way of treatment of the POWs. Hungary didn't return them back to Germany, and also the Vichy Government tried to protect and help them in Hungary. They accommodated mostly next to the Balaton or in the western parts of Heves County - about the latter István Lagzi wrote essay in 1981. ${ }^{8}$ Beyond the French prisoners of war various authors published smaller essays about the British, Italian, Romanian, Russian soldiers, who got caught in Hungary. Their fate was summarized by Károly Kapronczay in his aforementioned book.

The fates of the Czechs are not described in detail in the previously listed works. The reason is that they were illegal border crossers, so they fell out - de iure - from the group of prisoners of war during research. They only came up when the forced Jewish emigration is the topic. The Nazis wanted to expel the Jews from the Protectorate in 1939, with the same methods as they did in Germany earlier. István Flesch wrote about the Czech Jews, ${ }^{9}$ but as a part of the bigger wave, which used the Danube as their main migration route. Similarly, Károly Kapronczay also mentioned the Czech Jews, in his introductory essay before the memoirs of József Antall Sr. ${ }^{10}$ István Lagzi mentioned in one of his last book the Czechs, ${ }^{11}$ who wanted to flee through Hungary using almost the same route as the Poles did. He recalls two documents from the Hungarian National Archive about the illegal border crossers from the Protectorate, but he has not analyzed that even Czechs fled through Hungary.

In the Czech and Slovak literature the history of these refugees are well researched. In the sixties the first publications came out about the people, who fled to the Western Allies, about the "západáci". Toman Brod was one of the first authors, who wrote books, essays about the Czechs, who fled through Hungary during the Second World War. After the decades of detailed research, Jozef Leikert ${ }^{12}$ and Martin Hetényi ${ }^{13}$ published about entries into Slovakia from the Protectorate, or from Slovakia to Hungary.

\section{The Czechs in the Reports of the Hungarian Diplomats}

The first emigrants fled through the polish border from the occupied Czech lands during

7 Ego sum gallicus captivus - Francia menekültek Magyarországon, BAJOMI LÁZÁR, Endre (ed.), Budapest 1980.

8 LAGZI, István: Lengyelek és franciák Heves megyében, 1939-1945, Eger 1981.

9 FLESCH, István: Az isztambuli menedék: Törökország a vészkorszakban, Budapest 2010.

10 ANTALL, József Sr.: Menekültek menedéke, Budapest 1997, 1-21; József Antall Sr. (1896-1974): Hungarian jurist and politician. As an official of the Ministry of Interior during the World War II, he organized the treatment of the Polish refugees.

11 LAGZI, István: Lengyel katonák evakuációja Magyarországról-1939-1941, Budapest-Szeged-Varsó 2015.

12 LEIKERT, Jozef: Prechody studentov do československej zahraničnej armády po zatvorení českých vysokých skôl cez Slovensko, in: Slovensko v dejinách 20. storočia. Kapitoly k spoločenským a vojensko-politickým udalostiam. K 70. narodeninám PhDr. Mariána Hronského, DrSc., ČAPLOVIČ, Miloslav - STANOVA, Maria a kol., Bratislava 2010.

13 HETÉNYI, Martin: Slovensko-Madarské pomedzie v rokoch 1938-1945, Nitra 2008. 
the spring and summer of 1939. The Hungarian General Consulate (Magyar Királyi Fökonzulátus) in Prague had rather true information about their flight most of the time. It's worth to mention that this diplomatic mission was the successor of the Hungarian Embassy in Prague: after the German occupation, it was demoted, and subordinated under the Hungarian Embassy to the Third Reich in Berlin, while the Czechoslovakian Embassy in Budapest was shut down gradually after 15 March. $^{14}$

The maintenance of the Consulate General meant also that the Hungarian Ministry of Foreign Affairs had news about the exiles from the first hand. János Wettstein ${ }^{15}$ and later Ferenc Marosy ${ }^{16}$ in some of their reports mention names and numbers of these Czech exiles. Marosy in his report of 25 June wrote about 163 officers and warrant officers, who had already left Gdynia to France, and remained other eighty of them, who waited for their shipment. ${ }^{17}$ After the fall of Poland he sent to Budapest a particular report about the organized flight of the Czechs which now went through the Balkan. He mentioned nearly 160 people, who had already reached France in January of 1940. Also he wrote about the French Consulate General in Budapest, which helped the Czechs in their way to their Army in Exile. Marosy had information about certain people, who left the Protectorate in illegality: General Jaroslav Fajfr - the former head of the Czechoslovakian Air Force Ladislav Karel Feierabend and Jaromír Nečas - two former ministers. ${ }^{18}$

In Budapest, the Political Department of the Ministry of Foreign Affairs (Külügyminisztérium Politikai Osztálya) also had information about the Czechs. In this case the Ministry collected the news from the foreign Diplomatic Missions, who helped and gave shelter for the refugees. Mainly they were Poles, who had their semi-official organization to set up their flight to Yugoslavia. ${ }^{19}$ The Czechs in Hungary didn't have this kind of support, so they needed the help of the diplomatic missions in Budapest. The British Embassy in April of 1940 wanted to give a pack of underclothes for the Czechs, who were imprisoned in the Citadella - also the secretary of the Embassy, H. A. F. Hohler wanted to inquire their complain about their treat. ${ }^{20}$ These foreign diplomats sometimes didn't understand why the Hungarian officials made differences between the Poles and the Czechs. In their answer the Hungarian functionaries often recalled that the Czechs are illegal border crossers, and

14 ZUDOVÁ-LEŠKOVÁ, Zlatica: Zapomenutá elita: Českoslovenští vojenští diplomaté v letech 1938-1945, Prague 2011, 31.

15 János Wettstein (1887-1972): Hungarian diplomat who was the Hungarian envoy to Czechoslovakia from 1933 to 1939, during the World War Two he served in Switzerland, where he remained even after his retirement.

16 Ferenc Marosy (1893-1986): Hungarian diplomat who served as consul general in Prague after the German occupation from 1939 to 1941. After the World War Two he was delegated to Madrid by Hungarian National Committee (Magyar Nemzeti Bizottság), where he served until 1969.

17 Magyar Nemzeti Levéltár Országos Levéltár (National Archives of the Hungarian State Archives, hereinafter referred only as: MNL-OL), fund Külügyminisztérium (Ministry of Foreign Affairs, hereinafter referred only as: KÜM), K63, bound 72, item 7, No. 3703/939

18 MNL-OL, KÜM, K63, bound 72, item 7, No. 6253/1940/VII. res

19 Further reading: VARGA, László E.: Jan Emisarski vezérkari alezredes, budapesti lengyel katonai attasé múködése, 1938-1940, in: Aetas 25, 2010, 1, 122-123; and PRZEWÓŹNIK, Andrzej: Polacy w Królestwie Węgier 1939-1945, online: http://budapeszt.msz.gov.pl/resource/f6287a0f-964f-4ce2-8805-89c8aab77b6e.

20 MN-OL, KÜM, K63, bound 72, item 7, No. 2002/pol-1940 
not war refugees. For example the Hungarian Envoy to France, Sándor Khuen-Héderváry ${ }^{21}$ explained the differentiation with nearly the same words, adding that every government punishes these kinds of illegal entries. ${ }^{22}$

These anti-Czech or anti-Beneš behavior were common. Khuen-Héderváry in Paris said to an official of the French Ministry of Foreign Affairs, that "Central Europe after the war for twenty years was under the dictatorship of Beneš". ${ }^{23}$ As the leader of the Political Department of the Ministry of Foreign Affairs Jenö Ghyczy ${ }^{24}$ told Christian de Charmassé, the Secretary of the French Embassy: "For that matter, we don't have any special reason whatsoever that we should be permissive and benevolent in particular towards the Czechs." ${ }^{25}$ A couple of months later, on 9 April 1940 Ghyczy met with Robert C. Dexter, who was the emissary of the Unitarian Service Committee in Europe. With his wife, Dexter made a round trip in Central Europe to examine the treatment of refugees. During the meeting Dexter admitted, that Hungary handled well the Poles, but for the Czechs the circumstances were not satisfying. He asked the reason of that. Ghyczy in his answer recalled that apart from the two decade long oppression of the Hungarian minority in Czechoslovakia, "the Czechs can't be considered as refugees, because in Prague, they have a recruitment office for their legions, and they leave the Protectorate through Hungary." 26

Through the examples it's clear that the Hungarian Government had double standards towards the Czechs: they were under double pressure about them from the western diplomats, envoys and from the German Embassy. Germany pushed the Hungarian Government to expel the Czechs and Poles back to their land, which was under occupation. The German diplomats also asked the Hungarian Ministry of Foreign Affairs (Külügyminisztérium) that why they let Czech work at the French Embassy, because they are organizing the escape of their fellow countrymen. The Germans also had detailed information about the persons who worked there. However the Hungarian side denied the claim that the Czechs were privileged and treated well. The Hungarian argument stressed that this was impossible, because of Trianon and the prison guards couldn't be corrupted. ${ }^{27}$

\section{The Czechs on the Papers of the Ministry of Interior}

To control or coordinate the border crossers, the Hungarian Ministry of Interior also had very detailed information about the refugees. The local police, gendarmerie and border guard stations informed Budapest about the traffic on the border. Some of these reports went to the Ministry of Foreign Affairs too, to have more precise information about the

21 Sándor Khuen-Héderváry (1881-1947): Hungarian diplomat who served as the Hungarian envoy to France from 1934 to 1941. In 1947 he died under suspicious circumstances.

22 MNL-OL, KÜM, K63, bound 72, item 7, No. 500/940

23 Diplomáciai iratok Magyarország külpolitikájához, 4. volume, JUHÁSZ, Gyula (ed.), Budapest $1962,561$.

24 Jenő Ghyczy (1893-1982): Hungarian diplomat and politician, who was the leader of the Political Department of the Ministry of Foreign Affairs from 1939 to 1941, then he became as the first deputy of the Minister of Foreign Affairs. From 1943 until the German occupation of Hungary he served as the Minister of Foreign Affairs.

25 MNL-OL, KÜM, K63, bound 72, item 7, No. 8263/1939

26 MNL-OL, KÜM, K63, bound 72, item7, No. 988/940

27 MNL-OL, KÜM, K63, bound 72, item 7, No. 12303/1940/VII. res 
refugees. For the Ministry of the Interior it was important to know about these people, because - according to them - the uncontrolled refugees could be even spies in Hungary during the War. The Ministry also ordered to collect the Czechs, and transport them to jail. Some of them were in military prison, because they were the members of the former Czechoslovakian Army - but by the law they were illegal border crossers as well.

The number of the Czechs was lower than the number of the Poles, but the Ministry of Interior created a specific decree for their case. The decree number 16.988/1939 VII. res ordered the local police and administrative officers that if they caught border crossers from the Protectorate Bohemia-Moravia, they have to hand them over to the Budapest Police Headquarters Jail and Deportation Department (Magyar Királyi Rendórség Budapesti Fókapitánysága Fogház és Toloncosztály). ${ }^{28}$ Those people who didn't have passport were closed in for maximally two weeks, and after their imprisonment they were expelled from Hungary. If somebody had suspicious documents, their departure from Hungary had to be blocked temporally to investigate the origin of the papers.

In most cases the deportation meant that the Czechs had to leave the State towards Slovakia, whence they entered to Hungary. Or the Czechs were transported to the German border, because they were also the subjects of the Third Reich. The Hungarian Government wanted to avoid the political conflicts. Due to this, the Budapest Police Headquarters informed the Central Office for Control of Foreigners (Külföldieket Ellenörzó Országos Központi Hatóság - KEOKH) that the deportation of the Czechs to Yugoslavia can cause diplomatic problems, so the Police suggested the deportations towards Romania. ${ }^{29}$ As it was mentioned above, the German side would have the option to protest, if Hungary transported the Czechs to Yugoslavia. In the other hand deportation back to Slovakia or Germany could worsen the reputation of Hungary in London or Washington.

The process of the deportation often surprised the Czechs: it is mentioned in many memoirs, that the Hungarian soldiers fulfilled their duty carelessly. ${ }^{30}$ The Hungarian soldiers at the border told their prisoners that they could be shot, if they try to cross the border again. Normally the Hungarian border guards had to wait for a German or Slovakian border patrol to pass over the Czechs, but in many cases they left them alone. Some memoir writers or interviewed veterans decided to come back and cross Hungary again to Yugoslavia. ${ }^{31}$ Due to their experiences, for the second time they were mostly successful, but some of them stayed in Slovakia and not risked the dangerous trip again to enlist their Army in Exile. It is worth mentioning that the German diplomats had some information about this chain of events, however, the Hungarian Ministry of Foreign Affairs declared it as nonsense because of its complexity. ${ }^{32}$

Through the reports of the border guard the ministry had detailed picture about the Czechs. They knew where the exiles crossed the border, and how they travelled to Budapest. The first way of transport was the train, but it also was the most dangerous one, because the Czechs didn't speak Hungarian. To buy a ticket, and guide them to the right train, the

28 MNL-OL, Belügyminisztérium (hereinafter referredto only as: BM), K149, bound 215, item 2, No. 8255/1940.10

29 MNL-OL, BM, K149, bound 216, item 2, No. 5268/pol-1940

30 MELIŠEK, Ladislav: U Tobrúku, Veselí nad Moravou 2008, 53; Interview with Vilém Dvořák, online: http://www. pametnaroda.cz/index.php/story/dvorak-vilem-1921-385 (Downloaded 25 March 2016)

31 Ibidem.

32 MNL-OL, KÜM, K63, bound 72, item 7, No. 12303/1940/VII. res. 
French Embassy sent assistants to the railway stations, or they paid some locals for the help.

In a report from the detectives of the Police Station of Komját (Komjatice) ${ }^{33}$ the Ministry got a precise description of an organized support group. In Léva (Levice) Mrs. Breznyánszki's house was the secret meeting point, where Sándor Mihálka helped the Czechs. Rudolf Szklenár and Mihály Szlezák transported the exiles from the border to Léva. From the town, Mihálka and Béla Bus carried the Czechs to the train station of Verebély (Vráble), where Mihálka bought the tickets to Budapest. This report also mentions that some of the Czech after their entry to Hungary went straight to the Restaurant Paduff in Verebély. The detectives also wrote about how the Czechs recognized their helper at a railway station. At Hull (Hul) this person cough three times into a handkerchief, which was in his left hand, then wiped his forehead with it. After the meeting the refugee gave ten pengo for the help. The second method of transportation to Budapest was the use of a car. The previous report from Komját also mentions that a car owned by László Johanik from Özdöge (Mozjesovo, earlier known as Izdeg) was used for this purpose. For the police in Budapest, Johanik became suspicious: his Opel Kadett was often seen in the capital of Hungary. A police report described that on 18 September 1940 his car stopped before the French Embassy, and two people got out from it. ${ }^{34}$ During an interrogation Johanik explained the method of this kind of transportation. In April he transported three Czechs from the Catholic Dean of Özdöge to the Margaret Bridge. After this, he made other fifteen trips with new destinations. About the next transports he was informed by the carried refugees and he got also ciphered telegrams - to misguide the Police. The Czechs paid for him after the travel between $50-85$ pengős. ${ }^{35}$

The role of the French Embassy was well known by the Hungarian Ministry of Interior. Aladár Boór, the Chief of the Public Safety Department (Közbiztonsági Osztály) warned the French envoy, that they have to cease to issue passports for the Czech exiles. ${ }^{36}$ They were in safety at the Embassy, but the place was not enough spacious for them, so they were transported into safehouses. The Hungarian detectives described it as human smuggling in their reports. They also informed the Ministry of Interior about their raids against these places. During a raid on the 3 February in 1940, the Hungarian police arrested ten Czech and Slovak citizens in a safehouse not so far from the French Embassy. ${ }^{37}$ On 28 February twenty-six Czechs, seven Poles and five Slovaks were caught at a hiding place: three of them had valid documents, so they remained free - but the others were arrested, and the Royal Hungarian Police Jail and Deportation Department took them over. ${ }^{38}$

To leave Budapest, the French Embassy also helped to buy train tickets, or they guaranteed a car to reach the southern border of Hungary, where the Czechs could illegally enter Yugoslavia. Some of them crossed the Dráva (Drava), but it could be difficult. To get to Yugoslavia through Bácska (Bačka) was more popular, because there were no geographical

33 MNL-OL, BM, K149, bound 214, item 2, No. 24/15-1940

34 MNL-OL, BM, K149, bound 214, item 2, No. 5510/pol. res. 1940

35 MNL-OL, BM, K149, bound 214, item 2, No. 370/Bün. 1940

36 MNL-OL, KÜM, K63, bound 72, item 7, No. 423/940

37 MNL-OL, BM, K149, bound 216, item 2, No. 1951/B. kt. 1940

38 MNL-OL, BM, K149, bound 215, item 2, No. 739/pol. res. 1940 
obstacles. They did not use the crossing points, because they feared that their forged documents from the French Embassy would result their arrest.

\section{Examples of the Official Care: Two Reports about the Citadella}

The Czechs in custody were held at various locations, even within Budapest. The most common place was the Toloncház at the Mosonyi Street, next to the Keleti Railway Station. Originally the Toloncház was set up for 1,800 people in the eighties of the $19^{\text {th }}$ century. During the years of 1939, 1940 and 1941 the Toloncház had 19,038, 20,662 and 24,469 inmates per year. ${ }^{39}$ These numbers could show us why the level of the care was so low in this institution. Some of the Czech exiles were held in military barracks. The Maria Theresa Barrack and the Citadella were the two buildings owned by the Army, where Czechs were interned during 1939-1940. About the latter Jenő Zilahi-Sebess, the deputy leader of the Press and Cultural Department of the Ministry of Foreign Affairs (Külügyminisztérium Sajtó és Kulturális Osztálya) composed a detailed report.

During the first half of 1940 the Ministry was asked questions about some imprisoned people from various diplomatic missions. The Hungarian diplomats abroad had to answer to similar questions. In Paris Václav Kalina, the Czechoslovak military attaché to France also asked Budapest through Sándor Khuen-Héderváry to release Colonel Bruno Sklenovský. The Ministry of Defence denied this request, referring to the fact he was a professional officer of the Czechoslovakian Army. ${ }^{40}$ Later the British Embassy and the Apostolic Nunciature also asked about Sklenovský, who was ill at the time. The British envoy met with János Vörnle, ${ }^{41}$ who was the permanent deputy of the Hungarian Minister of Foreign Affairs. The envoy heard some information about the Citadella. As he knew there were eighty-four Czech people in the fortress, who had to sleep on lousy straw mattresses. Also, they suffered due to the lack of heating during the winter; furthermore they didn't receive medical care. It was impossible to wash their clothes too. On 11 February, some of them tried to escape. Two Czechs were caught and got beaten up by the guards. Five witnesses were closed into a dark cell as punishment. The rest was also punished: for two days they didn't get any kind of food. ${ }^{42}$

To investigate these claims, the Ministry of Foreign Affairs asked a report for the Ministry of Defence. In this detailed report of 1 April, they published the name of the 117 interned Czechs in Hungarian transcription. Also, there was a detailed description of their treatment. They ate the same two kinds of menus as the guards. As example to the report a menu card from March 21 to 30 was attached. It was also mentioned, that the inmates got wine at Easter and the Hungarian holidays. The Czechs also had two times per day two hours for sports and leisure. For washing themselves, the exiles had bowls and limitless water and once a week they were escorted to the Rácz or Rudas Bath, for that occasion their guards wore only their side weapons. ${ }^{43}$

39 A 60 éves magyar rendőrség 1881-1941, BORBÉLY, Zoltán, KAPY, Dezső dr. (eds.), Budapest 1941, 573.

40 MNL-OL, KÜM, K63, bound 72, item 7, No. 1357/pol-1940

41 János Vörnle (1890-?): Hungarian politician and diplomat who served from 1938 to 1941 as the permanent deputy of the Foreign Minister, later became the Hungarian envoy to Turkey. After the German occupation he remained in his position.

42 MNL-OL, KÜM, K63, bound 72, item 7, No. 1258/1940 Appendix

43 MNL-OL, KÜM, K63, bound 72, item 7, No. 1258/1940 
Three weeks later Jenő Zilahi-Sebess visited the Citadella, and also wrote a report about it. ${ }^{44}$ He confirmed some statements from the previous report, but his script had new information as well. As he witnessed on 22 April during his half hour long visit, ninety Czechs and Slovaks were interned - many of them considered themselves as Czechoslovaks. These inmates had quarters for every thirty people, and the size of these places was the same that were used by the guards, who were around forty. The food of the prisoners was also the same that the guards received. Zilahi-Sebess also confirmed the washing bowls, but he reported that the weekly visits of the baths nearby had ceased, because the Czechs used these trips as an occasion to escape. They didn't have a proper bathroom, but that was to be constructed. The toilets were in poor condition, because the prisoners didn't keep them clean - they would be also renovated.

Zilahi-Sebess wrote about the daily routines as well: after the waking up, the Czechs received the breakfast, but they got up individually. The guard commander told to ZilahiSebess, that around ten o'clock the inmates started to get dressed. After that they had one and a half hour to do sports or to take a walk, but they could do these during the afternoon too. Zilahi-Sebess also heard about the water carrying, which needed normally 28-30 people. If they didn't have any other work to do, the prisoners had to stay in their quarters. Some of them learnt languages or played with board games in their free time. Also a Polish monk from the Paulines visited them occasionally.

The sick inmates were transported to the $8^{\text {th }}$ Garrison Hospital. The Czechs were not allowed to listen to the radio, read newspapers, write letters or receive visitors. The canteen was also closed, but if they missed something, they asked the guards, who delivered the needed goods for them. If somebody had money, the prisoners sent their clothes to a laundry. The others washed the clothes with their hands and they got soap for that. The report also mentioned that thirty interned were Jewish and received financial support from the Budapest Jewish Community.

The author of the second report left the Citadella with an impression that the Czechs didn't keep that much of an order like the guards did. He also mentioned that there were attempts to escape, and the smuggling was still common. Zilahi-Sebess notified with curiosity that the previously mentioned Polish inmates wrote and drew on the wall. For example a citation from the Bible: "Father, forgive them, for they do not know what they are doing." 45 They also depicted the Virgin Mary as Patronae Hungaria and Justitia with a pig.

The difference between the two reports is clear. The first was an official answer to the negative claims of the British envoy, while the second one was more detailed and realistic. However the list from the first report is relevant: in this 117 people are soldiers who became important during the Second World War. For example: the above mentioned Bruno Sklenovský in 1941 became the Chief of Staff of the Ministry of National Defense in London and he held this position until 1945. ${ }^{46}$ Jaroslav Šustr was also in the Citadella, and later he became the trainer of the Czechoslovak special forces, who carried out various missions in the Protectorate of Bohemia-Moravia. From 1944 he was the Czechoslovak military attaché to China. ${ }^{47} \mathrm{He}$ also trained Jan Hrubý, who was another inmate of the fortress in April

44 MNL-OL, KÜM, K63, bound 72, item 7, No. 988/940

45 Lk 23:34

46 Vojenské osobnosti československého odboje 1939-1945, Jaroslav LÁNíK (ed.), Prague, 2005, 259-260.

47 Ibidem, 293. 
of 1940. Hrubý was the member of the Operation Bioscop. During the June of 1942 he lost his life along with the members of the Operation Anthropoid that attempted to kill Reinhard Heydrich the deputy Protector of the Protectorate. ${ }^{48}$

The British envoy heard rumors about the escapes, and Zilahi-Sebess also wrote about them. A listed inmate, Ladislav Melišek mentioned the successful escape attempt of Jaroslav Šustr, ${ }^{49}$ It was possible that the Czechs were punished because of the breakout and that they were given restrictions, but the second report also mentioned that the prisoners were not cut off completely from the outside world. The imprisoned Czechs sometimes got help from the Hungarian officials, however this was not official, and was not very common. The police report informs us about first lieutenant Müller who worked as translator at the Ministry of Defence. He mentioned that the Czechs had to report in the Toloncház at Elek Bodó, a retired police commissioner and lawyer suggested to them. Later, Béla Németh police chief counselor would arrest the Czechs for one hour, but after that the exiles could leave for a hotel. ${ }^{50}$

\section{The Official Expel from Hungary in 1940}

As it was mentioned before, the foreign diplomats often asked about the Czech Refugees in Hungary and there was also a great political pressure about their release or expel. In 1940 these diplomatic events became more frequent, while the prisons were overcrowded. The Hungarian Government finally decided to release of the Czechs. They were not as many as the Poles, so they were sacrificed; the German pressure eased and the Czechs could also continue their flight to their Army in Exile. They also disappeared from the Hungarian prisons.

In the papers of the Ministry of Foreign Affairs (which were quoted before) the query about the situation of the Czech exiles was only just part of the interest that was shown by the foreign diplomats. The other part was composed from questions about the release of the Czechs. Robert C. Dexter also asked about this during a meeting with Jenő Ghyczy. Dexter proved to be one of the most problematic people. He had good relations with the Czech emigrants in the USA. Also his Unitarian Universalist Church in the previous years tried to defend and help the Hungarian Unitarian people in Transylvania, ${ }^{51}$ thus - by the implicit decision of the Hungarian Embassy in Washington - he became a persona grata in Hungary as well.

The mission of Dexter was the final step in the process of releasing the Czechs officially. The meeting with Ghyczy took place on April 9: two weeks later Zilahi-Sebess paid an official visit to the Citadella. The Hungarian side possibly realized what the report of Dexter could mean in the American newspapers. By the time Dexter's colleague, Donald A. Lowrie arrived to Hungary in order to inspect this situation in May 1940 the Czechs had mostly been released already. Just a few of them remained in Hungary, and the Citadella was emptied as well - as Lowrie stated in his letter to Dexter. ${ }^{52}$

48 Ibidem, 107-108.

49 MELÍŠEK 2008, 44.

50 MNL-OL, BM, K149, bound 215, item 2, No. 5268-54

51 MNL-OL, KÜM, K63, bound 85, item 10, No. 42/biz

52 Harvard University Library, Unitharian Universalist Service Committee Records, Box 4, Folder 73/179, bMS 
The Hungarian Government probably tried to avoid further echoes of disapproval in the democratic countries. The newspapers informed the readers about the situation of the Czechs in Hungary. Thus not only the German diplomatic pressure caused great problems, but the articles in the American newspapers too. Antal Ullein-Reviczky, ${ }^{53}$ the chief of the Press Department of the Ministry of Foreign Affairs reported arranged a meeting with the local representatives of the Associated Press and United Press to ask them for support in their attempt of repelling this press attack against Hungary. ${ }^{54}$ The Chief of the Press Department also offered a visit to the Citadella which was empty at the time. Both of these representatives answered that they knew that the Citadella is empty, but still they wanted to visit places where the Czechs were still imprisoned.

Ullein-Reviczky tried to defend his stance: he told the two journalists that he can gather information and organize their visit, but it would take a long time - and it might turn out that this information would be useless for them. Finally at the meeting the representatives had an agreement with Ullein-Reviczky: they would publish a short article, if a Hungarian newspaper will wrote something against the Czech claims. However, Ullein-Reviczky wasn't satisfied with the compromise. He closed his report by saying that he would meet Domokos Szent-Iványi, who managed the American propaganda at the Prime Minister's Office. Since this field of propaganda got out of the hand of the Press and Cultural Department of the Ministry of Foreign Affairs still numerous American complaints arrived at the wrong office added Ullein-Reviczky to the end of his report.

Besides the everyday work of these offices, Ullein-Reviczky tried to delay the foreign journalists' visit. It could have been a tactical step to hide the circumstances from the journalists, but it might have held up the process of expelling the Czechs from Hungary. Until the chief of the Press and Cultural Department collected the necessary permissions to visit the imprisoned Czechs, they could have been taken to the Yugoslavian border. It is also possible, because Lowrie in his letter at the end of May also mentioned that most of the Czechs were transported to the southern border of Hungary - before Ullein-Reviczky met the representatives of the two press organizations.

The papers of the National Archives of Hungary are not so informative about the official transportation to the border. Only a couple of reports or letters wrote about the expel of the Czechs. Later, they disappeared completely from the reports. A possible reason behind this was that the Czech refugees were not so important, and the government was relieved: at that time the western propaganda about the Hungarian neutrality and the justification of the received territories were urgent, so that the diplomats and ministers could focus their attention on these important issues.

One of the last mentions of the Czechs in 1940 after the visit of Dexter was in the letter of Jenő Ghyczy, who wrote it to the Hungarian envoy in Washington, János Pelényi. ${ }^{55}$ In his letter, Ghyczy told Pelényi that the Czechs had already left Hungary and they weren't

161144, No. (73)-11

53 Antal Ullein-Reviczky (1894-1955): Hungarian politician, diplomat, who was the leader of the Press and Cultural Department from 1938 until 1943, when he became the Hungarian envoy to Sweden.

54 MNL-OL, KÜM, K63, bound 85, item 10 - without notation: the edge of the paper was cut off where there was the number of this report.

55 János Pelényi (1885-1974): Hungarian diplomat who was the envoy of Hungary to the USA from 1933 to 1940. When Hungary joined to the Tripartite Pact, he abdicated from his position. 
handed to Germany. ${ }^{56}$ This letter was written on 26 May, when Donald Lowrie witnessed the empty cells. Pelényi informed Dexter about the release of the Czechs and the letter from Lowrie also supported this fact. That's why Dexter sent a letter to the First Secretary of the Czecho-Slovakian Legation in Washington, Karel Červenka, informing him that the Czechs were practically released by the Hungarian officials. ${ }^{57}$

\section{Conclusion}

By using the documents of the National Archives of Hungary, the official treatment of the Czech refugees or the circumstances of it are reconstructable - although, with gaps. When the Czech emigrants arrived to Hungary, they were considered as illegal border crossers. They never got the political refugee status like the Poles did, so their official treatment was different. The reason behind this was both historical and political: in Hungary, the public opinion made the Czechoslovak leaders (especially Edvard Beneš) responsible for the Treaty of Trianon, and in 1939-1940, the officials took revenge on the exiles who wanted to join their Army in Exile that was organized by the Czechoslovak National Committee led by Beneš. The foreign diplomats in Hungary often asked the government to change the status of the Czechs, and didn't understand why the Hungarian officials differentiated between the Poles and the Czechs. The official answer to this question was that the Czechs crossed the border unofficially, and every country punishes this kind of activity.

Also Germany put pressure on Hungary through their embassy in Budapest. After the German occupation, the Czechs became citizens of the Third Reich, and Germany wanted to retrieve them. Other Embassies in Hungary tried to help the Czechs (their Diplomatic Mission was closed in Hungary after the start of the occupation in March of 1939): transporting them to Budapest, giving shelter and care, and finally issuing those documents for them that were needed to leave the country. The Hungarian ministries had detailed information about these actions from the police reports.

For the Teleki government, it was important to maintain the state of neutrality and the good image of Hungary in the democratic states. When the pressure grew bigger in 1940, unchecked news was also published in (mostly American) newspapers about the imprisoned Czechs in Hungary. These articles could worsen the picture of Hungary in the eyes of the public. Also, foreign journalists wanted to visit the Czechs to prove these claims. The government investigated the treatment of these exiles too, and tried to solve the problem. After the visit of Robert C. Dexter, who was the envoy of the American Unitarian Universalist Church, the Hungarian government suddenly released the Czechs, and they could leave the country towards Yugoslavia. The Dexter Mission was probably a decisive event in the history of the Czech refugees in Hungary. Dexter was a recognized person in the country, because he (and also his church) helped the Hungarian minority in Transylvania between the two world wars, and had good connections with the Hungarian officials.

The story of the Czech refugees is well traceable on the papers of the National Archives of Hungary. Although the Czechs spent little time in Hungary and their southern escape route existed only for two years, their case proved to be important for the Hungarian officials.

56 MNL-OL, KÜM, K63, bound 72, item 7, No. 1774/pol-1940.

57 Harvard University Library, Unitharian Universalist Service Committee Executive Director Robert C. Dexter Records, Box 2, Folder 1/4, bMS 16185 (24) 137. 
This topic is well-researched in the Czech Republic, but in Hungary, the story of the Czech refugees is barely known - also, the Czech historians didn't know much about the official care treatment of these people due to the lack of knowledge of the source language. The documents that were mentioned here are not only references, but examples showing that the National Archives of Hungary has primary sources that can broaden our knowledge about the Czechs during their flight from the Protectorate of Bohemia-Moravia.

\section{References}

Magyar Nemzeti Levéltár Országos Levéltára (National Archives of the Hungarian State Archives, MNL-OL), fund fund Külügyminisztérium, K63; fund Belügyminisztérium, K149 Harvard University Library

Unitharian Universalist Service Committee Records, available online: http://iiif.lib.harvard. edu/manifests/view/drs:25341768\$1i)

Unitharian Universalist Service Committee Executive Director Robert C. Dexter Records, available online http://iiif.lib.harvard.edu/manifests/view/drs:14718269\$1i ) Aetas 25., 2010

A 60 éves magyar rendőrség 1881-1941, BORBÉLY, Zoltán - KAPY, Dezső (eds.), Budapest 1941.

ANTALL, József Sr.: Menekültek menedéke, Budapest 1997, 1-21.

BROD, Toman: Cesty československých uprchlíků přes Balkán v letech 1939-40, in: Československo a Juhoslávia, REPÁŇOVÁ, Vilma (ed.), Bratislava, 1968, 400-405.

Diplomáciai iratok Magyarország külpolitikájához, Vol. 4, JUHÁSZ, Gyula (ed.), Budapest 1962.

Ego sum gallicus captivus - Francia menekültek Magyarországon, BAJOMI LÁZÁR, Endre (ed.), Budapest, 1980.

FLESCH, István: Az isztambuli menedék: Törökország a vészkorszakban, Budapest 2010.

GAZDA, István Sr.: Magyarországi lengyel katonai táborok postája 1939-1944, Piliscsaba 2000.

HETÉNYI, Martin: Slovensko-Mad'arské pomedzie v rokoch 1938-1945, Nitra, 2008.

HROZIENČíK, Jozef: K otázke slovensko-juhoslávskej solidarity v boji proti fašizmu, in: Československo a Juhoslávia, REPÁŇOVÁ, Vilma (ed.), Bratislava, 1968, 385-393.

Interview with Vilém Dvorák, online: http://www.pametnaroda.cz/ index.php/story/dvorakvilem-1921-385.

KAPRONCZAY, Károly: Lengyel menekültek Magyarországon, 1939-1945, Budapest 2009. LAGZI, István: Lengyelek és franciák Heves megyében, 1939-1945, Eger 1981.

LAGZI, István: Lengyel katonák evakuációja Magyarországról 1939-1941, Budapest Szeged - Varsó 2015.

LEIKERT, Jozef: Prechody studentov do československej zahraničnej armády po zatvorení českých vysokých skôl cez Slovensko, in: Slovensko v dejinách 20. storočia. Kapitoly k spoločenským a vojensko-politickým udalostiam. K 70. narodeninám PhDr. Mariána Hronského, DrSc., ČAPLOVIČ, Miloslav - STANOVA, Maria a kol., Bratislava 2010, 213-230. 
MELÍŠEK, Ladislav: U Tobrúku, Veselí nad Moravou 2008.

PRZEWÓŹNIK, Andrzej: Polacy w Królestwie Węgier 1939-1945, online: https://www.msz. gov.pl/ resource/f6287a0f-964f-4ce2-8805-89c8aab77b6e.

VARGA, László E.: Jan Emisarski vezérkari alezredes, budapesti lengyel katonai attasé múködése, 1938-1940, in: Aetas, 25, 2010, 1, 122-123.

Vojenské osobnosti československého odboje 1939-1945, LÁNíK, Jaroslav (ed.), Prague 2005.

ZUDOVÁ-LEŠKOVÁ, Zlatica: Zapomenutá elita: Českoslovenští vojenští diplomaté v letech 1938-1945, Prague 2011.

\section{Author}

Daniel Miklós

Bölcsészettudományi Kar, Eötvös Loránd Tudományegyetem

Faculty of Humanities, Eötvös Loránd University

Múzeum körút 4, 1088 Budapest, Hungary

petucco12@gmail.com 